\title{
Refuge
}

Canada's Journal on Refugees

revue canadienne sur les réfugiés

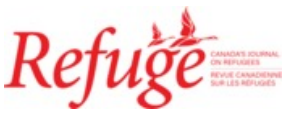

\section{Inhabiting Difference across Religion and Gender: Displaced Women's Experiences at Turkey's Border with Syria}

\section{Seçil Dağtaş}

Volume 34, numéro 1, 2018

Intersectional Feminist Interventions in the "Refugee Crisis"

URI : https://id.erudit.org/iderudit/1050854ar

DOI : https://doi.org/10.7202/1050854ar

Aller au sommaire du numéro

Éditeur(s)

Centre for Refugee Studies, York University

ISSN

0229-5113 (imprimé)

1920-7336 (numérique)

Découvrir la revue

Citer cet article

Dağtaş, S. (2018). Inhabiting Difference across Religion and Gender: Displaced Women's Experiences at Turkey's Border with Syria. Refuge, 34(1).

https://doi.org/10.7202/1050854ar

\section{Résumé de l'article}

La crise mondiale des réfugiés confère une nouvelle urgence aux questions de genre et de religion dans les contextes de déplacement. Cet article adopte, et alimente, une lecture féministe intersectionnelle des déplacements sexospécifiques en étudiant la vie quotidienne d'un groupe divers de femmes syriennes déplacées dans les territoires transfrontaliers du sud de la Turquie, pays qui accueille aujourd'hui la plus grande population de réfugiés au monde. J'argumente que les particularités de l'accueil et des passages de frontières qui rythment la vie de ces femmes conjuguent des pratiques sexospécifiques et des discours religieux d'une façon qui repense et transcende leur citoyenneté et leurs différences identitaires. De plus, ces particularités conjuguées permettent de dégager de nombreuses informations sur le travail des femmes et les réseaux quotidiens au niveau local, qui passent souvent inaperçues dans les débats publics. Les travaux de recherche qui déplacent leur intérêt de la gouvernance institutionnelle à la vie sociale quotidienne des femmes permettent aux féministes intersectionnelles de saisir les nuances des actes posés par les femmes déplacées et les imprévus concernant leur logement et leur mobilité au Moyen-Orient, les uns et les autres étant à mettre en perspective avec les représentations hors contexte historique des femmes réfugiées victimisées.
Copyright (c) Refuge: Canada's Journal on Refugees, 2018

Creative Commons Attribution NonCommercial 4.0 International License
Ce document est protégé par la loi sur le droit d'auteur. L'utilisation des services d'Érudit (y compris la reproduction) est assujettie à sa politique d'utilisation que vous pouvez consulter en ligne.

https://apropos.erudit.org/fr/usagers/politique-dutilisation/ 


\title{
Inhabiting Difference across Religion and Gender: Displaced Women's Experiences at Turkey's Border with Syria
}

\author{
SEÇIL DAĞTAȘ
}

\begin{abstract}
The global refugee crisis gives new urgency to questions of gender and religion in contexts of displacement. This article adopts and contributes to an intersectional feminist reading of gendered displacement by examining the daily lives of a diverse group of displaced Syrian women at the southern borderlands of Turkey, a country hosting the world's largest population of refugees today. I argue that the vernaculars of hospitality and border crossings surrounding these women's lives assemble gendered practices and religious discourses in ways that rework and transcend their citizenship and identity-based differences. These assemblages, moreover, derive significant insight from women's labour and everyday networks at the local level, which often go unnoticed in public debates. Research that shifts focus from institutional governance to women's everyday sociality allows intersectional feminists to capture the nuances of displaced women's agency and the contingencies of their dwelling and mobility in the Middle East against the de-historicized representations of victimized refugee women.
\end{abstract}

\section{Résumé}

La crise mondiale des réfugiés confère une nouvelle urgence aux questions de genre et de religion dans les contextes de déplacement. Cet article adopte, et alimente, une lecture féministe intersectionnelle des déplacements sexospécifiques en étudiant la vie quotidienne d'un groupe divers de femmes syriennes déplacées dans les territoires transfrontaliers du sud de la Turquie, pays qui accueille aujourd'hui la plus grande population de réfugiés au monde. J'argumente que les particularités de l'accueil et des passages de frontières qui rythment la vie de ces femmes conjuguent des pratiques sexospécifiques et des discours religieux d'une façon qui repense et transcende leur citoyenneté et leurs différences identitaires. De plus, ces particularités conjuguées permettent de dégager de nombreuses informations sur le travail des femmes et les réseaux quotidiens au niveau local, qui passent souvent inaperçues dans les débats publics. Les travaux de recherche qui déplacent leur intérêt de la gouvernance institutionnelle à la vie sociale quotidienne des femmes permettent aux féministes intersectionnelles de saisir les nuances des actes posés par les femmes déplacées et les imprévus concernant leur logement et leur mobilité au Moyen-Orient, les uns et les autres étant à mettre en perspective avec les représentations hors contexte historique des femmes réfugiées victimisées.
() Seçil Dağtas, 2018. This open-access work is licensed under a Creative Commons Attribution-NonCommercial 4.0 International Licence, which permits use, reproduction, and distribution in any medium for non-commercial purposes, provided the original authorship is credited and the original publication in Refuge: Canada's Journal on Refugees is cited.
Cette œuvre en libre accès fait l'objet d'une licence Creative Commons Attribution-NonCommercial 4.0 International License, laquelle autorise l'utilisation, la reproduction et la distribution de l’euvre sur tout support à des fins non commerciales, pourvu que l'auteur ou les auteurs originaux soient mentionnés et que la publication originale dans Refuge: revue canadienne sur les réfugiés soit citée. 
$\mathrm{T}$ The displacement of millions due to the ongoing war in Syria has alarmed the international public and drawn attention to the accompanying gender-based violence and religious persecution. Media outlets have documented accounts of sexual slavery of Yazidi women and the persecution of sexual and religious minorities by "Islamist" groups in Syria. ${ }^{1}$ Politicians and civil society actors in Western countries have debated prioritizing the "most vulnerable" (e.g., Christian Syrians or "women-and-children" ${ }^{2}$ ) for refugee sponsorship. ${ }^{3}$ Women and queer refugees have faced the need to mobilize gendered images of victimhood on religious and racial grounds to secure humanitarian assistance, legal protection, and political support. 4 These images often replicate the Orientalist portrayals of Middle Eastern women as sexually and religiously oppressed by patriarchal, homophobic, and violent-if not terrorist-Muslim men. 5 They underscore the need to situate problems of gendered displacement within a broader "matrix of domination"6 that includes patriarchy, racism, heterosexism, colonialism, nationalism, and other mutually constitutive systems of oppression.

Post-colonial and transnational feminists argue that the language of gender oppression can help justify "white, Western, and Christian racial and religious superiority" when divorced from other mechanisms of power. ${ }^{7}$ The sexual and religious subordination of women and queer people in Muslim societies often becomes a pretext for anti-immigrant rhetoric and border control in the West, ${ }^{8}$ and humanitarian interventions in the Global South. ${ }^{9}$ A feminist intersectional approach (emphasizing the interconnected nature of social identities and related power structures) is thus essential to debunk the deployment of such discourses for addressing the problems of displaced Syrian women. Yet this approach should not rely merely on a categorical understanding of social differences to describe the subjective experiences of this heterogeneous community. As scholars of homonationalism note, when bound to identitarian paradigms, intersectional frameworks categorize race, class, gender, and sexuality as distinct, commensurate, and pre-established markers of identity that intersect in specific domains of political life. ${ }^{10}$ As such, they fall short of capturing how these social categories themselves get constituted, assembled, and transcended in unpredictable ways within the actual relations of people under scrutiny. Moreover, these relations do not always concern encounters between Middle Eastern and Western liberal subjects in overtly political or bureaucratic domains of life. In the Middle East, where asylum laws and resettlement policies are less structured and more dependent on local responses than in their Western counterparts, ${ }^{11}$ displaced women negotiate their social roles and transcend their differences through ordinary relations of neighbourliness, kinship, and hospitality, often within the home space.
This article examines such negotiations at the southern borderlands of Turkey, a country hosting the world's largest population of displaced persons today (over three million) due to the Syrian war. ${ }^{12}$ I focus on the daily lives and struggles of a diverse group of displaced Syrian women, as these lives are shaped by the contingencies of their dwelling and movement in Turkey's province of Hatay, near the border with Syria. I argue that the vernaculars of hospitality and border crossing surrounding these women's lives present complex articulations of gender with religion vis-à-vis-but also beyond-their citizenship and identity-based differences. These articulations derive significant insight from women's labour and everyday networks at the local level, which often are dismissed as trivial in public and political debates.

Since the early days of the Syrian war in 2011, Hatay has been a major destination for displaced people, because it has geographic and historical connections to Syria, longestablished cross-border networks, and Arabic-speaking demographics. As of October 2017 Hatay is among the four provinces with the largest Syrian populations in Turkey. It hosts about 17,000 refugees registered in four camps and an estimated 400,000 in its towns and villages. ${ }^{13}$ In my longterm ethnographic research from 2010 to 2014 I examined the conditions of religious co-existence between diverse populations in Hatay's administrative capital Antakya, composed of bilingual (Turkish-Arabic) Alawis, Jews, Orthodox Christians, and Alevi and Sunni Turks, as well as a small number of Armenians. ${ }^{14}$ The data presented in this article, however, derive largely from my follow-up visits to the region over the summers of 2015 and 2016 for a total of three months, during which I interacted primarily with displaced Syrians.

Specifically I draw on participant observation in women's homosocial gatherings in Antakya, and on fifteen in-depth interviews with Syrian women aged twenty-two to seventy. Eight of these women came from middle-upper-class Sunni families from Aleppo with former business ties to the region, three were Orthodox Christians from Homs and Damascus, and the remaining four had previously lived in the countryside near Aleppo and Latakia before they came to Hatay. All interviews were semi-structured and audio-recorded and were conducted in Turkish, Arabic, and English, depending on the respondents' language skills and socioeconomic background. ${ }^{15}$ They took place during my regular visits to these women's houses, often after I had developed an understanding of the social context of their lives. These visits also situated our interaction in a hospitality context where my identity as a Turkish woman anthropologist from Canada was inflected, subsumed, and transcended by my status as a guest.

My data challenge the victimizing stories of sexual and gender-based violence under Muslim rule. Instead, the women's experiences register day-to-day interactions that 
entail cultural intimacy, reciprocity, and piety, as well as tensions and exclusions within gendered domains of hospitality. The forms of commitment and labour that women invest in these domains are inseparable from their ethnic, religious, and national affiliations. Yet they also express contingent assemblages of gendered practices and religious discourses that may be obscured by an identity-based intersectional reading and its presuppositions about "the character of those domains which are said to intersect." 16 This article addresses these assemblages, calling for an intersectional feminist approach that de-centres Western imaginations of the "refugee" and territorially bounded categories of citizenship beyond identitarian paradigms.

\section{Hatay as the Nexus of Nation and Religion}

Scholars approach the challenges of displacement by focusing on institutional processes. They examine how legislation and policy shape refugee life, ${ }^{17}$ and debate the agency of refugees in responding to such governance. ${ }^{18}$ Feminist scholars in particular effectively demonstrate the central role gender plays in the operation of, and responses to, asylum mechanisms by situating the experiences of displaced women and queer people in politico-legal contexts. ${ }^{19}$ Recent work on Syrian refugees maintains this focus on governance. While some scholars examine the regulation of Syrian refugees through global and national immigration regimes, ${ }^{20}$ others point to political structures and ethnoreligious factors to explain regional responses to the current refugee crisis. ${ }^{21}$ Studies of Syrian refugee women in Europe and the Middle East likewise address how they endure institutional marginalization, gender-based insecurities, and ethno-religious and legal violence. ${ }^{22}$

The legal and political conditions under which displaced Syrians arrive and settle in Turkey are indeed a vital component of their lived experiences. As a result of its "geographical limitation" policy towards the 1951 Refugee Convention and partial commitment to the 1967 Protocol, Turkey grants refugee status only to "citizens of member states of the Council of Europe" and provides temporary asylum for asylum seekers in third countries, with no prospect of long-term integration in Turkey. ${ }^{23}$ The recent arrivals from Syria, however, came under Turkey's impromptu "temporary protection regime," which espoused an open border policy for "Syrian guests" and provided them with "differential inclusion" in the form of legal access to health, education, and employment in some sectors. ${ }^{24}$ The future of Syrians in the country has nevertheless remained precarious. Turkey closed its southern borders in 2015 and is building a wall along them. It also signed a deal with the European Union in 2016 promising to accept mass returns of migrants from Greece in exchange for financial assistance. ${ }^{25}$ The uncertainties of national asylum policy and the limited involvement of the UNHCR in the resettlement of displaced Syrians in Turkey have made local politics and histories particularly influential in the lives of this population and their local hosts.

In the case of Hatay, the sociocultural impact of these recent demographic developments registers a longer history of shifting border regimes in the context of colonial relations and nation building. Formerly called the Sanjak of Alexandretta, the province was annexed to Turkey from French Mandate Syria in 1939, following a plebiscite that was state-managed from Turkey's capital, Ankara. ${ }^{26}$ The sanjak's delayed union with Turkey mitigated the effects of the national homogenization that characterized the transition from the Ottoman Empire to the Turkish Republic in the post-First World War era. This did not prevent the exodus and dispossession of its religiously diverse Arabophone and Armenian populations after the annexation, however. ${ }^{27}$ As outliers to the new republic's ideals of national homogeneity, the remaining kin of these communities faced assimilationist language, education, and population policies, along with economic restrictions and property ownership restrictions. Combined with the antiArab sentiments at the heart of Republican nationalism, which sought to align Turkey with "modern and secular Europe" rather than with the "Islamic Middle East," ${ }^{28}$ these measurements have led to the minoritization and further outmigration of the region's Jewish, Christian, and Alawi citizens. ${ }^{29}$

Although the annexation has divided communities and detached many from their extended kin, sanjak's residents have maintained religious, linguistic, business, and family ties with people in Syria, often through frequent and reciprocated visits across the border. In the early days of my fieldwork in 2010, I met Syrian women who had settled in Antakya after marrying into local families of the same religion, as well as Antakyans who had previously lived in Syria for university education or short-term business. While non-Sunni urban populations were mostly bilingual, older women in Hatay's Alawi and Christian villages knew little Turkish and spoke of distant relatives residing in northern Syria. Private taxis carried hundreds between Antakya and Aleppo each day, and many vendors in Antakya's "Syrian bazaar" relied economically on cross-border trade with Aleppine merchants. The 2009 Syria-Turkey Visa Waiver Agreement also led to the increased presence of Syrian tourists in Antakya, which many locals considered beneficial for business until mid-summer 2011. ${ }^{30}$

Despite these various forms of relatedness across the border, my long-term interlocutors in the region distinguish themselves from Syrians, often to avoid potential accusations and suspicions regarding where their true loyalty resides. This self-differentiation gained a stronger sectarian dimension after the Syrian war due to President Erdoğan's (Sunni) Islam-oriented divisive rhetoric, his anti-Assad and 
pro-rebel stance, and the rise of authoritarianism throughout the country. ${ }^{31}$ My contacts among the region's Arabophone Alawi and Christian populations, for instance, often expressed suspicions about pious Sunni Syrian refugees who fled the Assad regime and who have been "welcomed" by the governing Justice and Development Party. 32

Such suspicions have both historical and contemporary referents in the context of the Turkish state's role in the marginalization of these populations. People associate these recent demographic movements with different instances of governmental resettlements of Sunnis into the region throughout the history of modern Turkey. They also expressed anxiety over the cross-border mobility and violence of Sunni jihadist groups fighting in Syria. More often than not, however, both locals and Syrian newcomers inhabit multiple positionalities vis-à-vis each other, shifting between kin, neighbour, and enemy, depending on the context of their social interaction. As they have self-settled in Hatay by mobilizing formerly established networks and communal histories, or by engendering new bonds, the majority of displaced Syrians have become part of the local social fabric in urban and rural areas, rather than being confined to its refugee camps. Women's socialization within this fabric concerns their specific roles and labour within day-to-day relations of hospitality. These relations are imbued with power, hierarchies, and rivalry, as much as with intimacy, reciprocity, and affection. When women invoke religious discourse to narrate these relations, they emphasize the relational and ethical aspects of their religion, rather than its individualized or identity-based representations.

In what follows, I turn to vignettes from my fieldwork that illustrate how displaced women's everyday sociality simultaneously registers and transcends the differences across gender and religion beyond the formal structures of governance. If legal categories of (religious) minority and Syrian refugee build on the idea of the nation as bounded by naturalized borders, this sociality continuously unsettles such neat presentations and their manifestations.

\section{Ambivalences of Hospitality}

"The more you eat on this table, the more you love us, the more you love Allah," Aisha's mother (forty-five) remarks, when I try to politely decline her offer to fill up my plate with home-made pastries for the third time. I had known Aisha (twenty-seven) for over a month by then (June 2016), but this was my first visit to the two-bedroom duplex apartment she lives in with her family-her parents, her two younger sisters, and her husband, who works as a medical doctor in a Syrian health clinic in Antakya. ${ }^{33}$ Men are not at home in the afternoons, so Aisha tells me to be comfortable, to act "as in [my] own home," while removing her hijab and long coat that covers her jeans and T-shirt. I learn that their apartment belongs to an Alawi merchant with whom Aisha's father had close business ties prior to the conflict. "This is nothing like our house in Aleppo, but our landlord is a good man. God bless him," her mother says, and Aisha adds, "At least we don't live in one of these typical Syrian neighbourhoods; we may be the only Syrian family living in this district."

Indeed, the majority of displaced Syrians in Antakya populate low-income neighbourhoods, which are identifiable through Arabic signs on restaurants and shops, as well as by the graffiti on the street walls. Arab citizens of Turkey do not know how to read and write in Arabic. But they speak it well enough to make the city "feel like home" for many Syrians, as some remarked to explain to me why they settled in this part of the country. However, young women who wish to build a new life in Turkey, such as Aisha, see this as yet another challenge. "Everybody here speaks Arabic, so Syrians don't make the effort to learn Turkish," Aisha states, as we move from their fashionably decorated kitchen to the living room for afternoon coffee. "But we have to learn it if we don't want to be a guest or a refugee in this country forever."

Brought together at a kitchen table, the two registers of hospitality-the literal practices of feeding guests and the figurative framing of asylum as permanent guesthood-are central to the social roles and self-image of many displaced women I met in Antakya. They express different ways in which a mother and a daughter aspire to be a host and to belong in a country where they have been simultaneously welcomed and excluded as the state's "guests." Tahir Zaman observes that displaced Muslims who constitute the majority of the world's refugees today "read exile in majority Muslim countries as familiar and as home." 34 These groups reimagine their own migration through an Islamic narrative that builds on the pre-Islamic tradition of tribal hospitality toward strangers. These Islamic conceptions of home and mobility, Zaman further suggests, point to the fluidity of religious kinship beyond citizenship and envision territorial sovereignty as belonging to God rather than to the state. 35

For Syrian arrivals in Turkey, religious affinity (as well as difference) constitutes an ethical resource that shapes their social relations with locals from diverse ethno-religious affiliations. In offering more food, Aisha's mother invited me-a guest in her home and a host in the country where she resettled-to participate in a neighbourly and divine love, conjoined in an Islamic ethics of giving and receiving beyond the institutional domain of legal. "I am not Muslim for you or for myself," she later explained to me over coffee when I asked her to elaborate more on the relationship between feeding guests and loving God. "I am Muslim for God, and it is my duty as a Muslim to feed my guests properly, no matter who they are." The presentation of hospitality as a divine order unbound by 
specific identities erases the hierarchies that are intrinsic to the separation of the host from the guest. Aisha's comment about being a "refugee," by contrast, reminds us how these hierarchies of hospitality have come to define Syrian women's differential status in Turkey. This differential status, as both knew well, is not easy to resolve solely through abstract religious referents and their affective cadence.

Anthropologists have long described how local customs of hosting and visiting others are central to building and maintaining political alliances in Middle Eastern and Mediterranean contexts. ${ }^{36}$ Often less discussed is how these customs depend on women's labour and social networks, which are formed in less visible parts of the home space. The materiality of everyday hospitality-involving actual visits to the houses, the display of guestrooms, and verbal and ritualistic expressions of neighbourliness-requires women's often undervalued collaborative work in carefully seasoning, preparing, and serving food to the guests. ${ }^{37}$ This work often provides a common moral framework that connects women to each other across religion, kin, or socioeconomic class, while also harbouring hierarchies between them on other grounds. Anne Meneley calls this phenomenon "competitive hospitality" in her ethnography of how Yemeni women manifest their status and wealth in gender-segregated spheres of hosting. ${ }^{38}$ In research conducted in pre-war Syria, Christa Salamandra likewise considers Damascene women's customary morning coffee visits and monthly afternoon receptions as gendered sites of competitive display and markers of social distinction. 39

For Syrian women in Antakya, the coexistence of power and intimacy in home visits transforms ordinary categories of hospitality into shared linguistic tools to convey their experiences of social dislocation. Women particularly use these categories to describe difficulties in reciprocating and being recognized as "hosts" by the locals with whom they now have social relations. In July 2016, while we were preparing for a day-long trip to visit a number of Syrian refugee families residing in Hatay's border villages, an Alawi NGO worker repeatedly advised me to accept their offers of delicacies, even if I did not want to. When I questioned her insistence, she told me that it is common among local visitors to Syrians' houses to refuse such offers-a refusal that my Syrian interlocutors later confirmed they interpreted as denying them host status.

Such denial is particularly offensive to the Syrian women I met. The majority of these women, like Aisha's mother, spend their time at home while their husbands and sons work as occasional labourers in construction and the historic souk with a daily wage of 40 lira, half of what a local worker would make..$^{40}$ They receive aid from humanitarian agencies, which is vital but also controversial, since it causes friction with the locals who, according to some Syrian women, are also poor and thus jealous of the attention Syrians receive. "If the villagers visit us, they watch what we serve them," Naima (thirty-five) noted, "and then they either don't accept it, saying they have just eaten, or comment on how they can't afford this brand of cookie or that kind of tea ... you know, just to make us feel less proud, incompetent, or guilty."

Halima (forty-five) articulated the significance of visitation networks for social belonging when a sympathetic NGO worker told her, "You are here as guests, we do not think of you as refugees," during our visit to her single-bedroom unit in a low-income neighbourhood in Antakya. Simultaneously acknowledging and challenging the hierarchy implicit in this state-induced rhetoric of guesthood, she responded, "I am grateful to those of you who do not make me feel like a 'refugee,' who visit me and invite me to their homes, as neighbours would normally do."

Either as a religiously framed discourse, a metaphorical relationship, or an everyday practice, the vernaculars of hospitality assist displaced women in Antakya to cling-if tenuously-to a life interrupted by displacement. Notwithstanding the accounts of exclusion, hostility, and resentment, women also endure through the affinity they form with other women (both Syrian and local) via these vernaculars and practices. Some of these practices take more deliberate forms outside the home space in other parts of Turkey. For example, the neighbourhood initiative "woman-to-woman refugee kitchen" unites Turkish, Kurdish, and Syrian women around cooking in Istanbul's low-income districts. ${ }^{41}$ Others are built around shared religious idioms. For instance, the mawlids-religious ceremonies in which Islamic holy days are celebrated by reading passages from the Koran-are the main home-based activities through which Syrian Muslim women and their local neighbours gather and establish more reciprocal relations with one another. Echoing Aisha's mother's remarks about feeding in the name of God, women consider the food they serve in these instances as an ethical and religious obligation rather than a power-laden display of individual generosity.

Together, these practices present an alternative to the bio-political invocation of hospitality by governments, humanitarian organizations, and international law, as widely debated in migratory contexts. ${ }^{42}$ They remind us that hospitality as a "cosmopolitical right" 43 to be granted by nationstates and guaranteed by international law is just as gendered as its material manifestations in ordinary relations. It conjures an undifferentiated, gender-blind figure of the human or the citizen, while at the same time mobilizing visceral and domestic-like bonding with guests. 44 Such portrayals obscure both women's figurative and literal connections to the home space and their often-invisible labour in hosting others, and how this domestic-like bonding is experienced 
and expressed differently by men and women as well as by different women. They also raise new questions for feminist scholars of migration to tackle: what are the possibilities for producing a critical politics around displaced women's affective and social investments in hospitality given that these relations are already defined by social hierarchies and an asymmetrical division of labour between the sexes?

Following Jasbir Puar's take on the work of Deleuze and Guattari, ${ }^{45}$ I suggest that displaced women's hospitality relations in Antakya be understood not only as arenas of intersecting identities, but also as assemblages of diverse religious discourses, social categories, gendered practices, and reciprocated and unreciprocated relations. ${ }^{46}$ These assemblageslike the very category of the "Syrian refugee women"-are emergent, heterogeneous, and ephemeral in the nonetheless ordered social life. 47 They mobilize religion as a shared idiom that implies an ethical force of everyday interaction, as well as a marker of identity. When this social life becomes interrupted by wars, displacement, and multiple instances of legal and illegal border crossing, the individual biographies of these women become even more fragmented. The crossborder journeys of Yasmine (thirty-three) illustrate how this fragmentation produces unpredictable alliances along and beyond distinctively perceived social categories of religion, ethnicity, and gender.

\section{Bordering Encounters}

A self-identified devout Christian, Yasmine is originally from the city of Homs, where she worked as a translator in a tourism office and had met her husband-to-be, Hasim, a Christian mechanic. Shortly after their engagement, the war began and left them in two different neighbourhoods, one under the control of government forces and the other of the opposition. "Between his house and mine, there was one street that neither of us could cross without having the possibility of being killed," she said. "It was easier for both of us to come to and meet in Turkey than visit each other there."

Yasmine was the first to leave, and like thousands of Syrian nationals she could legitimately cross into Turkey from Yayladağ 1 using her passport. She stayed near a Christian family in Altinozu, where I first met her, helping them with housework and harvesting crops. She communicated with Hasim over Whatsapp for a year and a half, until Hasim hired a smuggler to help him enter Turkey through Cilvegozu, the second border crossing point between Hatay and Syria and one that was under IsIs control on the Syrian side. They were married in Turkey and had a child there, but because it was easier to cross the border into the regime-controlled areas of Syria than to get an appointment with the Syrian Embassy in Istanbul to register their daughter, they went back to Homs. "We also wanted to see if we could return. The situation was slightly better around where my family lived, but the living conditions were still harsh. We could not have any connection to Hasim's family, though. Their neighbourhood was completely destroyed.'

A month later, when IsIs was attacking Homs, Yasmine's mother told them to leave Syria for good, since they were constantly being interrogated by the regime's security because Hasim did not have a Syrian stamp on his passport. Yasmine explained, "It looks suspicious in Homs when neighbours see investigators entering your house all the time, as if we did something wrong. In our neighbourhood, many areas have Sunni, Shi'a, Druze, Ismaili, and Makdoushi people, as well as Maronite and Orthodox Christians. People there only think about their security and safety, they do not care about being pro-regime or anti-regime, they just don't want troublemakers in their neighbourhood. So we left again."

Back in Hatay the young couple kept their distance from other Syrians who populated the district they lived in to avoid being drawn in to the complexity of Syrian politics. "We have no relationship with Syrians here. They think differently than us. We don't want to talk about politics and be involved. But we have many Turkish friends, not only through the church, but from town, Muslims, Christians. We speak the same language and get along well." Hasim found his current job-repairing cars-through Turkish contacts (that is, Arabophone Turkish citizens) he made in the refugee camp where he stayed upon crossing the border for the second time. Yasmine came a few months later on a flight via Beirut and Istanbul. When I last saw them in the summer of 2016, they were renting the basement unit of the house owned by their church's priest's relative. They were thankful for the donations they received from the church and the support of the local community, but Yasmine wished to disown the "Syrian refugee" label: "When we go to the hospital, for instance, or on the street, they give me a look of repugnance. I do not wear the veil, so at first they think I am Turkish. But then when I speak they know I am Syrian. I see how nicely the nurses treat Turkish people, they open their office doors with smiles. If a Syrian knocked at their doors they do not smile ... In Syria we hosted the Lebanese refugees and Iraqis, we never frowned at them. Here, they treat us badly as Syrians instead of welcoming us."

Yasmine nostalgically defines pre-war Syria as shaped by a local conviviality between diverse religious communities and as welcoming of other displaced populations of the Middle East. This account resonates with anthropologist Dawn Chatty's analysis of Syria as "a refuge state." 48 Chatty claims that established traditions of religious cohabitation in the Middle East and forced migrations of minoritized communities into Syria (e.g., Armenians, Circassians, Palestinians) since the nineteenth century explains why so many Syrians escaping the conflict today have settled in the neighbouring 
countries of Jordan, Turkey, and Lebanon without registering with the UN as "refugees." Seeking "survival in dignity" 49 rather than legal asylum, displaced Syrians have relied on kin or other networks, coming and going across borders on the basis of the intensity of the conflict back home. Indeed, like Yasmine and Hasim, many Syrians I met in Hatay crossed the border multiple times in both directions and contemplated a potential return. Even after Turkey closed the border in 2015 and tightened its border security, there were occasions to go back. Some Syrians who crossed the border on foot into Syria from Hatay with the permission of the Turkish authorities for the 2017 Muslim Eid celebrations did not return..$^{50}$

Scholarly and popular references to Middle Eastern cosmopolitanism, however, tend to obscure how colonial, global, and regional power dynamics have historically shaped intercommunal interdependence and sectarian divides in the region, leading to the dispossession of its diverse populations. ${ }^{51}$ These dynamics inform the bureaucratic challenges and social exclusion that Yasmine identified after her national position shifted from host to guest. These resentments nevertheless coexist with small acts of care, cultural intimacy, economic support, and neighbourliness outside of institutional frameworks. Religion, in this context, is more than an affiliation whose identification is based on the presence or absence of its visible gendered markers, such as "the veil." It also works as an ethical and affective resource to endure displacement and its aftereffects. "I now leave everything to God," Yasmine said, by way of concluding our three-hour-long interview.

My husband and I have good intentions towards people, even though God has made it hard for us. He is testing us now to see whether we will keep following him or we will leave him. No, we will follow him ... In the midst of all the stress of having to leave our home in Damascus and to start a new life with nothing, I got pregnant, and my pregnancy test showed that my daughter might be born with a disability. I lived nine months through stress, but I knew that God wants me strong, so that my child will have strength and not weakness. So I gave birth to her, and she was the most beautiful of God's creation, a miracle, and our future. I know that God never leaves me, I always follow God.

Yasmine gave meaning to both her displacement and her motherhood through this account of a testing God, assured faith, and the reward of a "miraculous" birth. Her gendered body lay at the heart of Yasmine's piety and its narration, connecting the ordinary to the divine and the personal to the social, and ensuring the future of her family and kin. A mother, a wife, a Christian, a Syrian, an Arab, a guest, and a host, Yasmine simultaneously inhabited difference and transcended it in everyday sociality. As communal and national borders interrupt the order of her life, this sociality reassembles her gender roles, religious identity, and acts/narratives of piety in often unpredictable ways.

\section{From Intersections to Assemblages}

Just as there is no universal experience of displacement, there is also no universal "women's experience" of resilience and resistance in the face of discriminatory practices and victimizing narratives surrounding their lives in the camps, detention centres, and urban settings. An intersectional feminist approach provides the tools to identify the global power structures and local vernaculars of ethnicity, language, religion, and socioeconomic status informing the contingencies of being a refugee woman. The interdependency of the systems of oppression, however, does not mean that these social categories are equivalent or commensurable. As Joan Wallach Scott notes, racial difference often "works to establish the outsider status of those others who aren't part of the presumed homogeneity of the national body." 52 Sexual difference, by contrast, cannot be excluded from - and rather is vital to-the reproduction of that body. This conceptualization elevates the nation's women as sexual others above racial outsiders, as evident in the racial, sexualized, and religious framings of the "Syrian refugee" as an object of compassion or suspicion in the West.

Research that shifts focus from institutional governance to the everyday life of asylum complicates these exclusionary ideas of belonging and formalized hierarchies of suffering that are legally and semantically etched on to the "refugee" category. 53 The stories and lived experiences of Syrian women in Hatay reveals that these social categorizations, although influential, may not correspond to the realities of displaced women in practice. Not only do these women float across or disown the labels of refugee, asylum seeker, minority, or citizen; they often rely on other aspects of their lives, religious practices, and social relations to survive. They navigate spectrums of power in the house, on the street, among themselves, and vis-à-vis other men and women, rather than solely in their bureaucratic encounters with international humanitarian agencies or nation-states. Like Yasmine and Aisha, they sometimes align more with Turkish citizens of their own religious and linguistic communities or socioeconomic class than with other displaced Syrians or state and civil society actors.

Even subnational identity categories prove to be unstable and indeterminate in the social context of these alignments. Displaced Syrian and local Antakyan women become each other's kin, neighbour, friend, or enemy in gendered domains of everyday hospitality. These contingent (and expectedly reciprocal) positions evade being fixated on a particular ethno-religious identity, territorial belonging, or legal status. Women's everyday labour in less visible parts of the house is 
essential to establish and maintain these hospitality relations. When states or humanitarian agencies invoke the language of hospitality to frame their relations to displaced populations, they interrupt this reciprocal logic of relatedness, as implied in Aisha's references to her official guest status, Naima's and Halima's resentful accounts of hosting others, and Yasmine's memories of pre-war Syria and her cross-border journeys and bordering encounters. To make sense of these invocations, women turn once again to everyday life in which religion, gender, and ethnicity emerge, merge, and give meaning to each other in dynamic ways, rather than intersecting as pre-established identities. Perhaps we should look more to this life and the forms of assemblages it entails to present more nuanced understandings of displaced women's agency against the dehistoricized representations of victimized refugee women.

\section{Notes}

1 Rukmini Callimachi, "IsIs Enshrines a Theology of Rape," New York Times, August 13, 2015, https://www.nytimes .com/2015/08/14/world/middleeast/isis-enshrines-a-theology-of-rape.html.

2 Cynthia Enloe, Maneuvers: The International Politics of Militarizing Women's Lives (Berkeley: University of California Press, 2000), 26.

3 Lori Beaman, Jennifer Selby, and Barras Barras, "No Mosque, No Refugees: Some Reflections on Syrian Refugees and the Construction of Religion in Canada," in The Refugee Crisis and Religion: Secularism, Security and Hospitality in Question, ed. Luca Mavelli and Erin Wilson, 77-96 (Plymouth: Rowman \& Littlefield, 2016).

4 Katty Alhayek, "ICTs, Agency, and Gender in Syrian Activists' Work among Syrian Refugees in Jordan," Gender, Technology and Development 20, no. 3 (2016): 333-51; Jane Freedman, Zeynep Kivilcim, and Nurcan Özgür Baklacioglu, A Gendered Approach to the Syrian Refugee Crisis (London: Routledge, 2017); Maya Mikdashi and Jasbir K. Puar, "Queer Theory and Permanent War," GLQ: A Journal of Lesbian and Gay Studies 22, no. 2 (2016): 215-22.

5 Angie Abdelmonem, Rahma Esther Bavelaar, N. Elisa Wynne-Hughes, and Susana Galán, “The 'Taharrush' Connection: Xenophobia, Islamophobia, and Sexual Violence in Germany and Beyond," Jadaliyya, March 1, 2016, http:// www.jadaliyya.com/pages/index/23967/the-\%E2\%8o $\% 9$ Ctaharrush\%E2\%80\%9D-connection_xenophobiaislamophobia;Elena Fiddian-Qasmiyeh, "The Faith-GenderAsylum Nexus: An Intersectionalist Analysis of Representations of the 'Refugee Crisis," in The Refugee Crisis and Religion: Secularism, Security and Hospitality in Question, ed. Luca Mavelli and Erin Wilson, 207-21 (Plymouth: Rowman and Littlefield, 2016); Jill Walker Rettberg and Radhika Gajjala, "Terrorists or Cowards: Negative Portrayals of Male Syrian Refugees in Social Media," Feminist Media Studies 16, no. 1 (2016): 178-81.
6 Patricia Hill Collins, Black Feminist Thought: Knowledge, Consciousness, and the Politics of Empowerment (London: Routledge, 2002).

7 Joan Wallach Scott, Sex and Secularism (Princeton: Princeton University Press, 2017), 3.

8 Judith Butler, "Sexual Politics, Torture and Secular Time," British Journal of Sociology 59, no. 1 (2008): 1-23; Sherene Razack, "Imperilled Muslim Women, Dangerous Muslim Men, and Civilized Europeans: Legal and Social Responses to Forced Marriages," Feminist Legal Studies 12, no. 2 (2004): 129-74. Miriam Ticktin, "Sexual Violence as the Language of Border Control: Where French Feminist and Anti-Immigrant Rhetoric Meet," Signs: Journal of Women in Culture and Society 33, no. 4 (2008): 863-89.

9 Lila Abu-Lughod, Do Muslim Women Need Saving? (Cambridge, MA: Harvard University Press, 2013); Paul Amar, The Security Archipelago: Human-Security States, Sexuality Politics, and the End of Neoliberalism (Durham, NC: Duke University Press, 2013).

10 Karma R. Chávez, Queer Migration Politics: Activist Rhetoric and Coalitional Possibilities (Chicago: University of Illinois Press, 2013); Jasbir K. Puar, Terrorist Assemblages: Homonationalism in Queer Times (Durham, NC: Duke University Press, 2007); David Valentine, Imagining Transgender: An Ethnography of a Category (Durham, NC: Duke University Press, 2007).

11 Dawn Chatty, Displacement and Dispossession in the Modern Middle East (Cambridge: Cambridge University Press, 2010); Tahir Zaman, Islamic Traditions of Refuge in the Crises of Iraq and Syria (New York: Palgrave Macmillan, 2016).

12 According to the UNHCR, 28 per cent of forcibly displaced people are hosted in the Middle East and North Africa. Turkey, Pakistan, Iran, and Lebanon are the top refugeehosting countries, while the majority of displaced people come from Syria and Afghanistan. "Figures at a Glance," 2017, http://www.unhcr.org/figures-at-a-glance.html.

13 UNHCR, "UNHCR Syria Regional Refugee Response," 2017, http://data.unhcr.org/syrianrefugees/country.php?id=224.

14 Şule Can, "The Syrian Civil War, Sectarianism and Political Change at the Turkish-Syrian Border," Social Anthropology 25, no. 2 (2017): 174-89; Fulya Doğruel and Johan Leman, "'Conduct' and 'Counter-Conduct' on the Southern Border of Turkey: Multicultural Antakya," Middle Eastern Studies 45 (2009): 593-610.

15 Three of my respondents were able to speak and understand Turkish, as they had lived in the country for over five years. My Aleppine, Damascene, and Christian interlocutors were also proficient in English. Aisha, whom I introduce later in this article, accompanied me in seven of these interviews, during which she acted as an Arabic interpreter.

16 Valentine, Imagining Transgender, 17.

17 Didier Fassin, Matthew Wilhelm-Solomon, and Aurelia Segatti, "Asylum as a Form of Life: The Politics and Experience of Indeterminacy in South Africa," Current Anthropology 58, no. 2 (2017): 160-87; Vicki Squire, The Contested 
Politics of Mobility: Borderzones and Irregularity (London: Routledge, 2010).

18 Michel Agier, On the Margins of the World: The Refugee Experience Today (Cambridge: Polity, 2008); Cetta Mainwaring, "Migrant Agency: Negotiating Borders and Migration Controls," Migration Studies 4, no. 3 (2016): 289-308.

19 Linda A. Camino and Ruth M. Krulfeld, Reconstructing Lives, Recapturing Meaning: Refugee Identity, Gender, and Culture Change (London: Taylor \& Francis, 1994); Jane Freedman, Gendering the International Asylum and Refugee Debate, 2nd ed. (London: London, 2015); Alison Mountz, "Where Asylum-Seekers Wait: Feminist Counter-Topographies of Sites between States," Gender, Place \& Culture 18, no. 3 (2011): 381-99; David A. B. Murray, "Queer Forms: Producing Documentation in Sexual Orientation Refugee Cases," Anthropological Quarterly 89, no. 2 (2016): 465-84; Elena Fiddian-Qasmiyeh, The Ideal Refugees: Gender, Islam, and the Sahrawi Politics of Survival (New York: Syracuse University Press, 2014).

20 Nergis Canefe, "Management of Irregular Migration: Syrians in Turkey as Paradigm Shifters for Forced Migration Studies," New Perspectives on Turkey 54 (2016): 9-32; Alise Coen, "R2P, Global Governance, and the Syrian Refugee Crisis," International Journal of Human Rights 19, no. 8 (2015): 1044-58; Kim Rygiel, Feyzi Baban, and Suzan Ilcan, "The Syrian Refugee Crisis: The Eu-Turkey 'Deal' and Temporary Protection," Global Social Policy 16, no. 3 (2016): 315-20; Zümray Kutlu-Tonak, "Endless Escape: From Syria to Turkey, Then to Europe," Studies in Ethnicity and Nationalism 16, no. 1 (2016): 121-34.

21 Gülay Kılıçaslan, for instance, addresses the relations between Syrian Kurds and internally displaced Kurds in Turkey, "Forced Migration, Citizenship, and Space: The Case of Syrian Kurdish Refugees in Istanbul," New Perspectives on Turkey 54 (2016): 77-95. See also Seth M. Holmes and Heide Castañeda, "Representing the 'European Refugee Crisis' in Germany and Beyond: Deservingness and Difference, Life and Death," American Ethnologist 43, no. 1 (2016): 12-24; Annastiina Kallius, Daniel Monterescu, and Prem Kumar Rajaram, "Immobilizing Mobility: Border Ethnography, Illiberal Democracy, and the Politics of the 'Refugee Crisis' in Hungary,' American Ethnologist 43, no. 1 (2016): 25-37; Giulia El-Dardiry, "People Eat People: The Influence of Socioeconomic Conditions on Experiences of Displacement in Jordan," International Journal of Middle East Studies 49, no. 4 (2017): 701-19.

22 Katty Alhayek, "Double Marginalization: The Invisibility of Syrian Refugee Women's Perspectives in Mainstream Online Activism and Global Media," Feminist Media Studies 14, no. 4 (2014): 696-700; Lorraine Charles and Kate Denman, "Syrian and Palestinian Syrian Refugees in Lebanon: The Plight of Women and Children," Journal of International Women's Studies 14, no. 5 (2013): 96-111; Eda Erdener, "The Ways of Coping with Post-War Trauma of Yezidi Refugee Women in Turkey,' Women's Studies International Forum 65
(2017): 60-70; Jane Freedman, Zeynep Kivilcim, and Nurcan Özgür Baklacioglu, A Gendered Approach to the Syrian Refugee Crisis; Zeynep Kivilcim, "Legal Violence against Syrian Female Refugees in Turkey," Feminist Legal Studies 24, no. 2 (2016): 193-214.

23 For the impact of these policies on migrant flows prior to the Syrian conflict, see Kristen Biehl, "Governing through Uncertainty: Experiences of Being a Refugee in Turkey as a Country for Temporary Asylum," Social Analysis 59, no. 1 (2015): 57-75; Ahmet Icduygu, "Demographic Mobility and Turkey: Migration Experiences and Government Responses," Mediterranean Quarterly 15, no. 4 (2005): 88-99; Kemal Kirisci, "Disaggregating Turkish Citizenship and Immigration Practices," Middle Eastern Studies 36, no. 3 (2000); Kemal Kirisci, "Turkey: A Country of Transition from Emigration to Immigration," Mediterranean Politics 12, no. 1 (2007): 91-7; Ayse Parla, "Irregular Workers or Ethnic Kin? Post-199os Labour Migration from Bulgaria to Turkey," International Migration 45, no. 3 (2007): 157-81.

24 Feyzi Baban, Suzan Ilcan, and Kim Rygiel, "Syrian Refugees in Turkey: Pathways to Precarity, Differential Inclusion, and Negotiated Citizenship Rights," Journal of Ethnic and Migration Studies 43, no. 1 (2017): 41-57.

25 Rygiel, Baban, and Ilcan, "Syrian Refugee Crisis"; Canefe, "Management of Irregular Migration"; Kemal Kirişci, "Syrian Refugees and Turkey's Challenges: Going beyond Hospitality" (Washington, DC: Brookings, 2014), 14.

26 Roberta Micallef, "Hatay Joins the Motherland," in State Frontiers: Borders and Boundaries in the Middle East, ed. Inga Brandell, 141-58 (London: I. B.Tauris, 2006); Keith David Watenpaugh, "Creating Phantoms': Zaki Al-Arsuzi, the Alexandretta Crisis, and the Formation of Modern Arab Nationalism in Syria," International Journal of Middle East Studies 28 (1996): 363-89.

27 Berna Pekesen, "The Exodus of Armenians from the Sanjak of Alexandratta in the 1930s," in Turkey beyond Nationalism: Towards Post-Nationalist Identities, ed. Hans-Lukas Kieser, 57-66 (London: I. B. Tauris, 2006); Sarah D. Shields, Fezzes in the River: Identity Politics and European Diplomacy in the Middle East on the Eve of World War II (Oxford: Oxford University Press, 2011).

28 Martin Stokes, "Imagining 'the South': Hybridity, Heterotopias and Arabesk on the Turkish-Syrian Border," in Border Identities: Nation and State at International Frontiers, ed. Thomas M. Wilson and Hastings Donnan (Cambridge: Cambridge University Press, 1998), 268.

29 My interviews with members of these communities indicate that Antakya Jews migrated to Europe, Israel, and North America, and urban Christians mostly to Europe, while peasants from Alawi and Christian villages became temporary labour migrants in Gulf countries. Their younger generations, seeking better job or marriage prospects, have also moved to bigger cities in Turkey with larger Christian and Jewish populations, such as Istanbul or Izmir. According to their religious and political leaders as well as local 
historians, Arab Alawis constituted 30 to 40 per cent of the population in the province, while there were a few thousand Christians and less than 50 Jews prior to the arrival of Syrian nationals.

30 This visa agreement also enabled many Syrians fleeing the conflict to enter Turkey legally until Turkey unilaterally terminated it in 2016.

31 Can, "Syrian Civil War, Sectarianism and Political Change." 32 Seçil Dağtaş, "Whose Misafirs? Negotiating Difference along the Turkish-Syrian Border," International Journal of Middle East Studies 49, no. 4 (2017): 661-79.

33 Syrian university diplomas are not accredited in Turkey and thus cannot provide their holders access to work in health care or schooling. In the past, private schools and clinics run by Syrians for Syrians existed outside any legal framework, yet the provincial authorities tolerated them. Since 2014 the Turkish Ministries of Health and Education monitor the opening and operation of these institutions. European Council of Refugees and Exiles, "Asylum Information Database Country Report: Turkey," 2015, 132.

34 Zaman, Islamic Traditions of Refuge, 151-4.

35 Zaman, Islamic Traditions of Refuge, 30.

36 Matei Candea, "Derrida En Corse? Hospitality as Scale-Free Abstraction," Journal of the Royal Anthropological Institute 18, no. S1 (2012): S34-S48; Michael Herzfeld, "As in Your Own House': Hospitality, Ethnography, and the Stereotype of Mediterranean Society," in Honor and Shame and the Unity of the Mediterranean (Special Publication No. 22), ed. D. D. Gilmore (Washington, DC: American Anthropological Association, 1987), 75-89; Julian Pitt-Rivers, The Fate of Shechem: Or, The Politics of Sex: Essays in the Anthropology of the Mediterranean (Cambridge: Cambridge University Press, 1977); Andrew Shryock, “The New Jordanian Hospitality: House, Host, and Guest in the Culture of Public Display," Comparative Studies in Society and History 46, no. 1 (2004): 35-62.

37 Mayling Simpson-Hebert, "Women, Food and Hospitality In Iranian Society," Canberra Anthropology 10, no. 1 (1987): 24-34.

38 Anne Meneley, Tournaments of Value: Sociability and Hierarchy in a Yemeni Town (Toronto: University of Toronto Press, 1996).

39 Christa Salamandra, A New Old Damascus: Authenticity and Distinction in Urban Syria (Indianapolis: Indiana University Press, 2004), 58.

40 The only exception to this was women in the countryside who helped the men in their families during harvesting season to meet the strict work deadlines for no additional payment in return.

41 Nilay Vardar, "Woman to Woman Refugee Kitchen," Bianet-Bagimsiz Iletisim Agi, January 19, 2017, https://m.bianet.org/english/women/182834-woman-to-womanrefugee-kitchen.

42 Shahram Khosravi, "Illegal" Traveller: An Auto-Ethnography of Borders (London: Palgrave Macmillan, 2010); Mireille
Rosello, Postcolonial Hospitality: The Immigrant as Guest (Stanford: Stanford University Press, 2001); Katerina Rozakou, "The Biopolitics of Hospitality in Greece: Humanitarianism and the Management of Refugees," American Ethnologist 39, no. 3 (2012): 562-77. Cathrine Thorleifsson, "The Limits of Hospitality: Coping Strategies among Displaced Syrians in Lebanon," Third World Quarterly 37 no. 6 (2016): 1071-82; Burcu Koca, "Syrian Refugees in Turkey: From 'Guests' to 'Enemies," New Perspectives on Turkey 54 (2016): 55-75.

43 Şeyla Benhabib, The Rights of Others: Aliens, Residents and Citizens (Cambridge: Cambridge University Press, 2004); Jacques Derrida, Of Hospitality (Stanford: Stanford University Press, 2000).

44 Nina Høy-Petersen, Ian Woodward, and Zlatko Skrbis, "Gender Performance and Cosmopolitan Practice: Exploring Gendered Frames of Openness and Hospitality," Sociological Review 64, no. 4 (2016): 970-86.

45 Puar, Terrorist Assemblages.

46 Suzan Ilcan deploys the concept of "assemblage" to address the inherent contradictions of humanitarian regulation. "Paradoxes of Humanitarian Aid: Mobile Population, Biopolitical Knowledge, and Acts of Social Justice in Osire Refugee Camp," in Mobilities, Knowledge and Social Justice, ed. Suzan Ilcan, 177-206 (Montreal and Kingston: McGillQueen's University Press, 2013). My use of the term emphasizes its place in the lives of displaced populations rather than within the systems that regulate them.

47 George E. Marcus and Erkan Saka, "Assemblage," Theory, Culture \& Society 23, no. 2-3 (2006): 101-6.

48 Dawn Chatty, Syria: The Making and Unmaking of a Refuge State (London: Hurst, 2018).

49 Chatty, Syria, 243.

50 Umit Bektas, "Syrian Refugees Head Home on Foot from Turkey for Eid Holiday," Reuters, June 16, 2017, https://uk.reuters .com/article/mideast-crisis-turkey-syria-int/syriansrefugees-head-home-on-foot-from-turkey-for-eid-holiday-iduKKBN19622L.

51 Saba Mahmood, Religious Difference in a Secular Age: A Minority Report (Princeton: Princeton University Press, 2016); Robert B. Satloff, "Prelude to Conflict: Communal Interdependence in the Sanjak of Alexandretta 1920-1936," Middle Eastern Studies 22, no. 2 (1986): 147-80.

52 Scott, Sex and Secularism, 24.

53 Emma Haddad, The Refugee in International Society: Between Sovereigns (Cambridge: Cambridge University Press, 2008); Liisa Malkki, "National Geographic: The Rooting of Peoples and the Territorialization of National Identity among Scholars and Refugees," Cultural Anthropology 7, no. 1 (1992): 24-44.

Seçil Dağtaş is an assistant professor of anthropology at the University of Waterloo and a research fellow at the Collegium deLyon. She can be reached at sdagtas@uwaterloo.ca. 